\title{
Oxytocin Receptor mRNA Expression in the Ventromedial Hypothalamus during the Estrous Cycle
}

\author{
Tracy L. Bale, ${ }^{1}$ Daniel M. Dorsa, ${ }^{1}$ and Craig A. Johnston ${ }^{2}$ \\ 'Departments of Pharmacology and Psychiatry and Behavioral Sciences, University of Washington, Seattle, \\ Washington 98195 and ${ }^{2}$ Departments of Pharmaceutical Sciences, School of Pharmacy and Allied Health Sciences, \\ University of Montana, Missoula, Montana 59812
}

\begin{abstract}
Changes in OR mRNA expression in the ventromedial hypothalamus $(\mathrm{VMH})$ in relation to the estrous cycle were measured by In situ hybridization with a rat oxytocin receptor (OR) probe. Binding studies have localized ORs to various brain regions, and have detected a high density of receptors in the $\mathrm{VMH}$, a nucleus containing large numbers of estrogen responsive neurons. Previous studies in this lab have reported a significant increase in OR mRNA expression in the $\mathrm{VMH}$ in ovariectomized rats treated with estrogen. The present study was designed to determine whether changes in steroid hormone levels across the estrous cycle result in induction of OR mRNA expression. Autoradiographic studies revealed differences in $O R$ mRNA expression in the rostral and caudal as well as medial and lateral aspects of the VMH. OR mRNA levels were highest in the caudal portion of the vIVMH on the afternoon (16:00 hr) of proestrus. The rostral region exhibited a high level of expression in the ventrolateral region of the VMH on the morning (9:00 $\mathrm{hr}$ ) of proestrus and in the dorsomedial region of the $\mathrm{VMH}$ on the afternoon of proestrus. Little or no OR mRNA expression was evident in the rostral or caudal VMH on the morning or evening of diestrus. These results support previous findings which showed a regulation of OR binding by gonadal steroids and suggest that this may be due to altered expression of the OR gene. These effects suggest a possible role of ORs in the oxytocin stimulated release of luteinizing hormone.
\end{abstract}

[Key words: oxytocin receptor mRNA, in situ hybridization, ventromedial hypothalamus, estrogen, progesterone, estrous cycle]

Oxytocin, the neurohypophyseal hormone, functions in welldocumented roles in the processes of lactation and parturition (Smith, 1989). Its CNS neurotransmitter functions are less well understood. Oxytocin-containing neurons project widely throughout the brain and appear to innervate several brain regions in which specific oxytocin (OT) binding sites have been

\footnotetext{
Received Jan. 11, 1995; revised Feb. 23, 1995; accepted Feb. 27, 1995.

This work was supported by USPHS Grant NS-20311 (D.M.D.), the Department of Veterans Affairs (D.M.D.), Neurobiology Training Grant NS-07332 (T.L.B.), and the Alzheimer's Disease Research Center AG05136 (D.M.D.) of the University of Washington and by R29-MH48228 (C.A.J.) of the University of Montana. We thank Jennifer Tullis, Elaine Chen, and Michael Kuo for their laboratory assistance, Michael Hutnak for proofreading the manuscript, and Cong $\mathrm{Xu}$ and Veronica Hardy for their excellent technical support.

Correspondence should be addressed to Tracy L. Bale, Department of Pharmacology, SJ-30, University of Washington, Seattle, WA 98195.

Copyright (C) 1995 Society for Neuroscience 0270-6474/95/155058-07\$05.00/0
}

identified. Several CNS effects of oxytocin in females have been proposed including facilitation of maternal behavior (Pedersen and Prange, 1979; Fahrbach et al., 1985; Van Leengoed et al., 1987) and lordosis (Caldwell et al., 1986; Schumacher et al., 1989), as well as inhibition of learning and memory (Walter et al., 1975; Bohus et al., 1978; Ferrier et al., 1980; Fehm-Wohlsdorf et al., 1984). Other studies have provided evidence that central endogenous OT exerts a physiologically relevant stimulatory influence on luteinizing hormone (LH) secretion just prior to ovulation on the afternoon of proestrus in cycling females (Johnston and Negro-Vilar, 1988; Johnston et al., 1990). The intracerebral administration of oxytocin evoked a release of plasma LH on the afternoon of proestrus but not on metestrus or diestrus. This ability of oxytocin to stimulate $\mathrm{LH}$ release was highly dependent on the concentration and time of exposure of gonadal steroids (Johnston and Gelineau-VanWaes, 1992).

The locations of oxytocin receptors (OR) which might mediate these effects are not clear. Rat binding studies have localized oxytocin receptors to various brain regions including the hippocampus (Van Leeuwen et al., 1985; Tribollet et al., 1988), paraventricular nucleus (PVN) (Brinton et al., 1984), and the ventromedial hypothalamus (VMH) (DeKloet et al., 1985a; Tribollet et al., 1990). These binding sites were shown to be functional receptors by electrophysiological studies which documented changes in neuronal firing rates upon OT application (Raggenbaus et al., 1989).

Although binding studies have not detected a significant difference in OT binding between male and female rat brain (Tribollet et al., 1990), studies have shown OT binding in specific regions to be gonadal steroid sensitive (De Kloet et al., 1985b, 1986; Johnson et al., 1989; Tribollet et al., 1990; Johnson et al., 1991; Schumacher et al., 1993). Specifically, estrogen has been shown to increase OT binding sites in the VMH of both male and female gonadectomized rats. The anatomical distribution as well as the area containing receptor sites in the VMH have been reported to be further increased by progesterone in estrogen primed females, but not in estrogen primed males (Coirini et al., 1992; Schumacher et al., 1993). Although the area of binding in females was shown to increase, the density of OT binding over the cell bodies in the VMH was actually reduced. Data from our laboratory indicates that estrogen may increase OT binding in the VMH by initially enhancing OR mRNA expression (Bale and Dorsa, 1995).

The present study was designed to evaluate changes in OR mRNA expression in the VMH of intact females during two stages of the estrous cycle: one when estrogen levels are low 
(diestrus), and one when estrogen levels are high (proestrus). Our goal was then to determine if the marked differences in estrogen levels naturally present in these stages predicted the levels of OR mRNA expressed within the $\mathrm{VMH}$.

\section{Materials and Methods}

Animals. Adult female Sprague-Dawley rats (Simonsen Labs, Gilroy, CA), weighing $280-350 \mathrm{gm}$, werc houscd in a temperature $\left(23^{\circ} \mathrm{C}\right)$ and light (lights on from 7:00 hr to 19:00 hr) controlled environment and were supplied with food and water ad libitum. The estrous cycles of adult female rats were charted by observing changes in vaginal cytology monitored daily by vaginal lavage. Animals demonstrating two or more consecutive 4 d estrous cycles (estrus, metestrus, diestrus, and proestrus) were sacrificed at appropriate cycle stages. Confirmation of this phase of the cycle was obtained by examining vaginal cytology both on the morning of the experiment as well as postmortem, and by examining the uterine horns after sacrifice for characteristic proestrous ballooning. Ovaries were inspected for evidence of ovulation; no signs of ovulation were noted in any of the animals. After decapitation, trunk blood was collected into $15 \mathrm{ml}$ polystyrene tubes containing $0.5 \mathrm{ml}$ of $10 \%$ EDTA, and mixed immediately. All blood samples were kept on ice until centrifugation at $1000 \times g$ for $35 \mathrm{~min}$. Plasma samples were then stored at $-80^{\circ} \mathrm{C}$ until hormone radioimmunoassays could be done.

Preparation of RNA probe. A 283 bp fragment corresponding to the coding region of the rat $O R$, spanning a segment from the end of the putative II transmembrane domain through the end of the putative IV transmembrane domain, was amplified from a genomic clone as previously described (Bale and Dorsa, 1995). The amplified fragment was blunt-ended with Klenow (Promega) and inserted into pGEM7. The plasmid containing the insert was linearized with SacI for antisense probe and $\mathrm{XbaI}$ for sense probe. Antisense and sense riboprobes were transcribed using T7 and SP6 RNA polymerases (Promega), respectively, and ${ }^{35}$ S-UTP (Du Pont).

In situ hybridization. Coronal brain tissue sections $(20 \mu \mathrm{m})$ were cut on a cryostat onto 3-aminopropyltriethoxysilane-treated slides. Slides were processed and hybridized according to methods described previously (Bale and Dorsa, 1995). Briefly, slides with tissue were fixed in $4 \%$ paraformaldehyde, rinsed in PBS, immersed in acetic anhydride, and then dehydrated through a series of ethanol rinses and delipidated in chloroform. An ${ }^{35} \mathrm{~S}$-labeled antisense or sense (control) oxytocin receptor riboprobe was used to hybridize the tissue RNA in a $50 \%$ deionized formamide hybridization mix overnight at $55^{\circ} \mathrm{C}$ in a humidified incubation chamber. Following the incubation, slides were washed in $1 \times$ SSC $(0.15 \mathrm{M}$ sodium chloride and $0.015 \mathrm{M}$ sodium citrate, $\mathrm{pH} 7.0)$ at room temperature for $30 \mathrm{~min}$ with shaking, treated with $20 \mu \mathrm{g} / \mathrm{ml}$ RNase (Promega) at $37^{\circ} \mathrm{C}$ for $30 \mathrm{~min}$, rinsed in RNase buffer at $37^{\circ} \mathrm{C}$ for $30 \mathrm{~min}$, and washed three times for $20 \mathrm{~min}$ at $65^{\circ} \mathrm{C}$ in $0.1 \times \mathrm{SSC}$ with shaking, dehydrated in a graded series of alcohols containing ammonium acetate $(70 \%, 95 \%$, and $100 \%)$, air dried, and apposed to Kodak Hyperfilm (Eastman Kodak, Rochester, NY) for 1 week. After films were developed, slides were then dipped in NTB2 liquid nuclear emulsion (Eastman Kodak; diluted 1:1 with ammonium acetate), exposed for $21 \mathrm{~d}$, photographically processed, stained with cresyl violet, and coverslipped.

Data analysis. Film autoradiograms were analyzed using a microcomputer based image analysis system (MCID). Optical density measures from film autoradiograms of in situ hybridization for oxytocin receptor mRNA were obtained from the VMH of female animals. A one-way analysis of variance (ANOVA) and Fischer's least significant difference post hoc testing were used to evaluate differences in oxytocin receptor mRNA levels in the VMH of cycled females. Numerical values are reported as the mean $\pm \mathrm{SE}$. The personal computer program STATVIEW II (Abacus Concepts, Inc., Berkeley, CA) was used for statistical analysis of the data.

Hormone radioimmunoassay. Plasma samples were assayed within the same radioimmunoassay (RIA). LH was assayed by double antibody RIA using supplies generously provided by the NIDDK (NIDDK Rat Pituitary Hormone Distribution Program, University of Maryland School of Medicine). LII values were expressed in terms of rLII RP-3 standard and had an intraassay coefficient of variation of $8 \%$, with a limit of sensitivity of $0.5 \mathrm{ng} /$ tube. Plasma estradiol and progesterone were assayed using a double antibody RIA (Diagnostic Assay Services, Gaithersburg, MD). The sensitivities of the RIAs were $1.0 \mathrm{pg} / \mathrm{ml}$ and
Table 1. Mean hormone values from plasma of female rats sacrificed on stated day of estrous cycle assayed by radioimmunoassay

\begin{tabular}{rllll} 
Time & Day of cycle & $\begin{array}{l}\text { LH } \\
(\mathrm{ng} / \mathrm{ml})\end{array}$ & $\begin{array}{l}\text { Estradiol } \\
(\mathrm{pg} / \mathrm{ml})\end{array}$ & $\begin{array}{l}\text { Progesterone } \\
(\mathrm{ng} / \mathrm{ml})\end{array}$ \\
\hline $9: 00$ & Diestrus & $3.2 \pm 0.2$ & $26.4 \pm 4.7$ & $16.7 \pm 1.1$ \\
16:00 & Diestrus & $3.6 \pm 0.3$ & $32.3 \pm 5.5$ & $13.8 \pm 1.5$ \\
$9: 00$ & Proestrus & $4.0 \pm 0.3$ & $49.2 \pm 6.8^{a}$ & $12.5 \pm 1.0$ \\
$16: 00$ & Proestrus & $4.5 \pm 0.4$ & $86.5 \pm 8.9^{b}$ & $31.0 \pm 2.9^{b}$ \\
\hline
\end{tabular}

Values represent mean $\pm \operatorname{SEM~(~} n=8$ /group).

"Significant difference between both 9:00 and 16:00 of diestrus $(p<0.05)$.

"Significant difference between all other measured time points within the group $(p<0.05)$.

$1.0 \mathrm{ng} / \mathrm{ml}$ for estradiol and progesterone, respectively, with intraasay coefficients of variation of $8 \%$ and $11 \%$, respectively.

\section{Results}

\section{Hormone levels}

Luteinizing hormone, estradiol, and progesterone levels were measured in cycled animals at designated times on dicstrus and proestrus (Table 1). LH levels were low at all times examined, indicating that animals sacrificed on the afternoon (1600 hr) of proestrus had not yet experienced a preovulatory LH surge. Estradiol levels were significantly higher on proestrus versus diestrus. In addition, plasma estradiol levels were significantly higher at 16:00 hr on proestrus compared to 9:00 hr proestrous values. In contrast, plasma levels of progesterone were significantly elevated only on the afternoon of proestrus compared to levels on the morning of proestrus or at either time on diestrus.

\section{In situ hybridization film and slide analyses}

Oxytocin receptor mRNA expression was measured in the VMH of female rats at a known stage of the estrous cycle by measurement of optical density on film autoradiogram. A distinct pattern of expression, which differed in the rostral and caudal VMH at two different stages of the cycle was observed. Hy bridization signal in the rostral portion of the VMH was significantly elevated on the morning (9:00 hr) of proestrus in comparison to either the morning $(9: 00 \mathrm{hr})$ or afternoon $(16: 00 \mathrm{hr})$ of diestrus, and was slightly higher than levels on the afternoon $(16: 00 \mathrm{hr}$ ) of proestrus (Figs. 1, 2). Region specific anatomical differences were also detected in the medial and lateral VMH. Hybridization signal was evident in the ventrolateral aspect of the $\mathrm{VMH}$ on the morning of proestrus, but exhibited a more dorsal and medial distribution on the afternoon of proestrus (Fig. 1). Hybridization signal in the caudal portion of the VMH was greatest on the afternoon of proestrus and remained low at all other times studied (Figs. 3, 4). Expression was only observed in the vlVMH at this stage (Fig. 3). Microscopic analysis of emulsion coated slides further substantiated the rostral-caudal difference in expression and more clearly localized expression to the vl versus $\mathrm{dm}$ regions (Fig. 5).

\section{Discussion}

The purpose of this study was to examine the anatomical location and magnitude of OR mRNA expression in the VMH during the estrous cycle using in situ hybridization techniques and a previously characterized rat OR probe (Bale and Dorsa, 1995). Variations in expression of OR mRNA were detected in both the rostral-caudal and the medial-lateral aspects of the $\mathrm{VMH}$, 


\section{Diest A.M.}
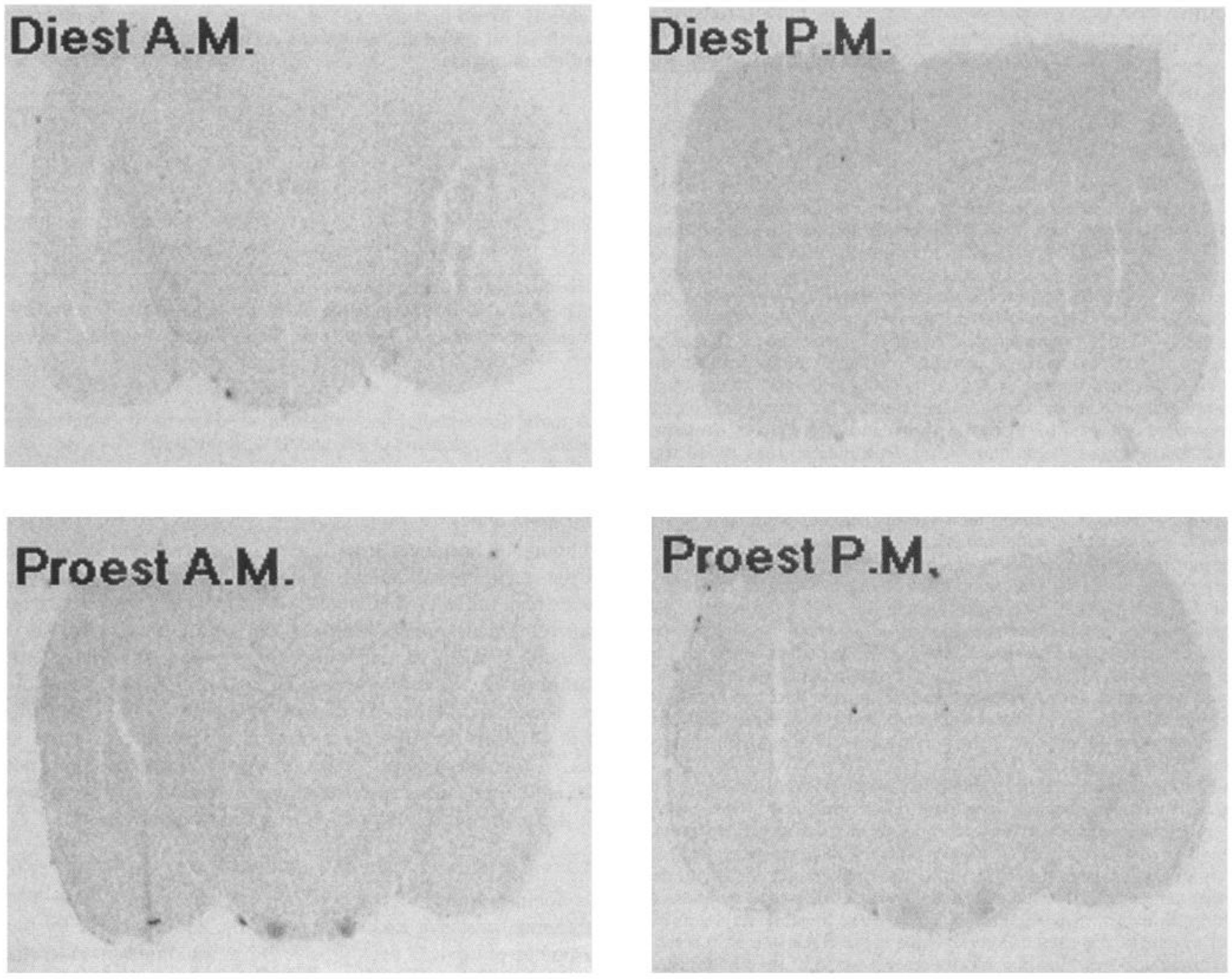

\section{Proest P.M,}

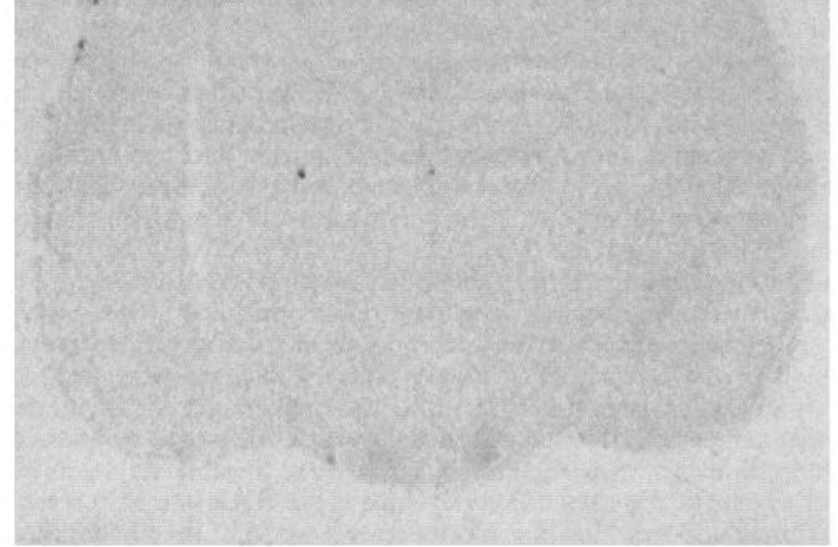

Figure 1. Representative photomicrographs of film autoradiograms of brain sections from cycled female rats containing the rostral VMH hybridized with an ${ }^{35} \mathrm{~S}$-labeled rat OR riboprobe. Brains were analyzed for OR mRNA at 9:00 hr and 16:00 hr of diestrus and proestrus. Hybridization signal is most evident in the vlVMH on the morning of proestrus and in the dmVMH on the afternoon of proestrus.

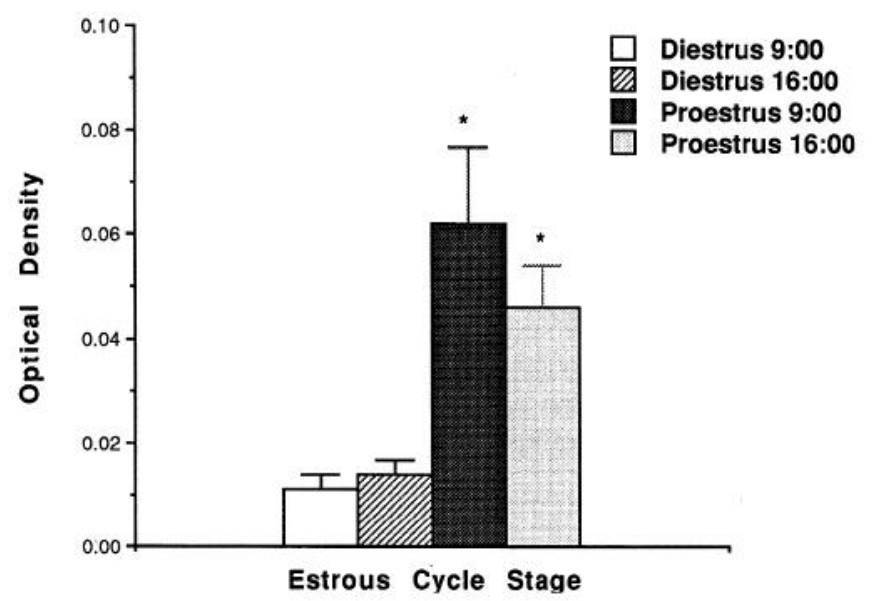

Figure 2. Quantification of optical density changes in the rostral vIVMH of OR mRNA on diestrus and proestrus. OR mRNA expression was significantly greater at proestrus 9:00 hr and proestrous 16:00 hr in the rostral vlVMH when compared to both diestrus times $\left(^{*}, p<\right.$ $0.05)$. Values are the mean \pm SEM. and the most prominent expression was localized to the vlVMH. Expression in the caudal region of the vlVMH was highest on the afternoon of proestrus and was only weakly present at all other stages. In contrast, expression in the rostral region was highest on the morning of proestrus, slightly decreased on the afternoon of proestrus, and essentially absent on the morning and afternoon of diestrus. Interestingly, the expression in the rostral region of the $\mathrm{VMH}$ changed from the ventrolateral division in the morning to the dorsomedial portion on the afternoon of proestrus. Since estrogen levels were maximal on the afternoon of proestrus, these findings would in part be consistent with our previous studies which showed that estrogen treatment of ovariectomized females significantly increased OR mRNA expression in the caudal region of the vlVMH (Bale and Dorsa, 1995). Further, previous binding studies have shown that estrogen more significantly increases OT binding in the caudal division than in the rostral portion of the VMH (Johnson et al., 1989).

Previous studies have reported a change in the anatomical distribution of OT binding sites in the VMH when estrogen 


\section{Diest A.M.}

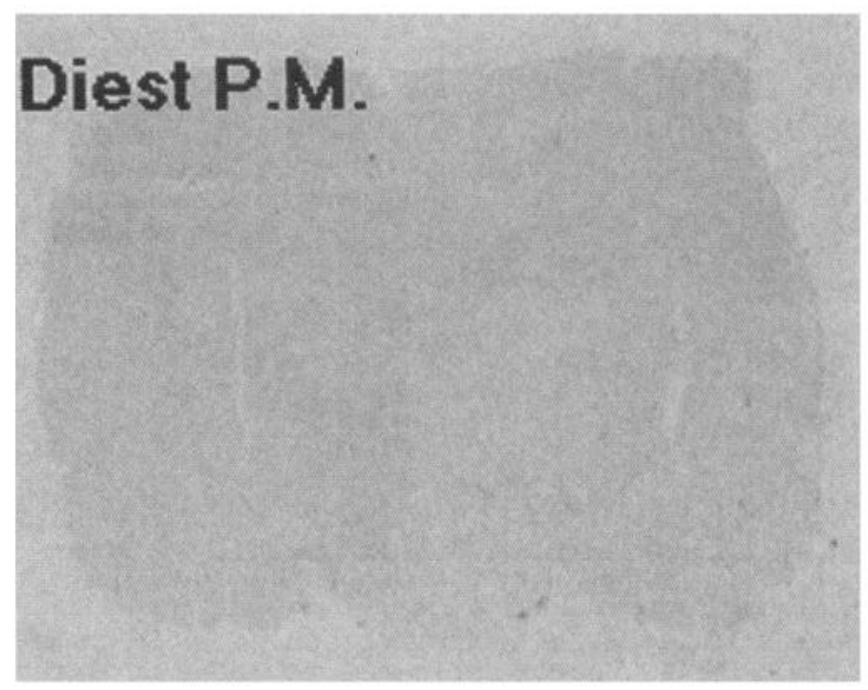

\section{Proest A.M.}
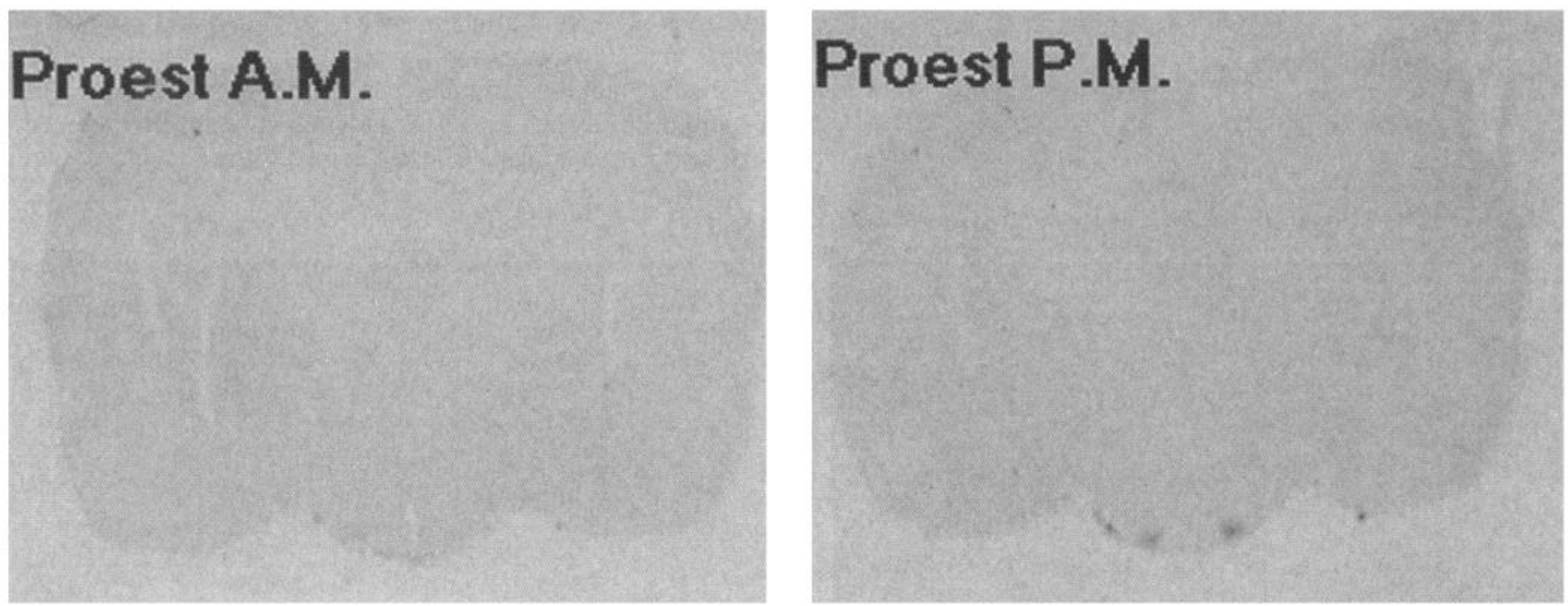

Figure 3. Representative photomicrographs of film autoradiograms of brain sections from cycled female rats containing the caudal VMH hybridized with an ${ }^{35} \mathrm{~S}$-labeled rat OR riboprobe. Brains were analyzed for OR mRNA expression at 9:00 hr and 16:00 hr of diestrus and proestrus. Significant expression was evident only in the vlVMH on the afternoon of proestrus.

primed females were given progesterone (Schumacher et al., 1990; Coirini et al., 1992). This enlargement of the area encompassing OT binding requires estrogen priming for induction and progesterone for its maximal spread (Coirini et al., 1991). This observation is intriguing since OT immunoreactive axons are only found in the zone surrounding the ventrolateral part of the $\mathrm{VMH}$, and has not been detected in the central portion of this nucleus (Schumacher et al., 1989). In light of this, McEwen and collaborators have suggested that this movement of receptors to the lateral aspects of the nucleus may bring them in proximity to OT itself, possibly due to transport of ORs to other VMH neuronal compartments, that is, dendrites (Coirini et al., 1991).

Our studies have shown that OR mRNA is predominantly expressed in the vlVMH. Projections from this region of the VMH intercept many if not all the extra hypothalamic regions of the brain which have been shown to contain OT binding sites, including the central nucleus of the amygdala and the ventral tegmental area (Canteras et al., 1994). This suggests that the ORs are synthesized within the vlVMH and then transported to the terminals of these neurons which project to other nuclei.
Therefore, detection of OR mRNA changes in the VMH might be informative as to OR protein concentrations at some of these distal sites.

The lateral movement of the VMH ORs induced by progesterone is thought to be important in the mechanism by which sexual behavior/receptivity is induced in rats given oxytocin and progesterone (Schumacher et al., 1990; Witt and Insel, 1991). OT is important in initiating sexual (lordosis) behavior in female rats given estrogen and progesterone (Arletti and Bertolini, 1985; Caldwell et al., 1986; Gorzalka and Lester, 1987). This behavior was blocked by antisense oligonucleotides to the progesterone receptor or the oxytocin receptor, when injected or infused into or near the VMH (Pollio et al., 1993; Mani et al., 1994; McCarthy et al., 1994; Ogawa et al., 1994). Further, antagonists to the OR also attenuate progesterone facilitation of female sexual behavior (Caldwell et al., 1990; Witt and Insel, 1991). The importance of both estrogen and progesterone is also evidenced by the fact that when given OT, females primed only with estrogen demonstrate a significantly lower (Shumacher et al., 1989) or no measure of lordosis response (Gorzalka and 


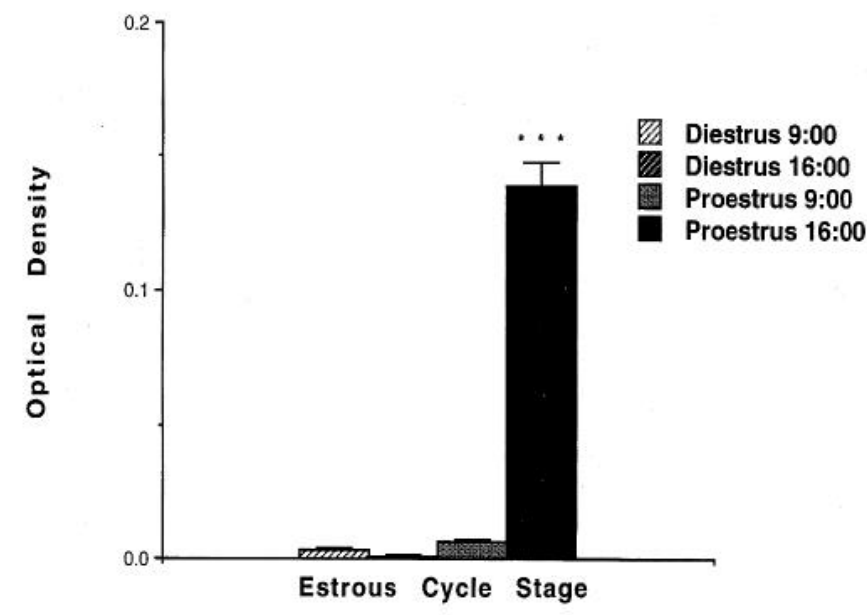

Figure 4. Quantification of optical density changes in the caudal vlVMH OR mRNA on diestrus and proestrus. OR mRNA expression in the caudal vlVMH was significantly higher on the afternoon of proestrus than at all other measured times. Values are the mean \pm SEM $(* * *, p<0.0001)$
Lester, 1987) than those given both estrogen and progesterone. Since interference with expression of either the progesterone or oxytocin receptors reduces or even blocks female sexual behavior, both OT and progesterone receptor occupancy may be necessary for normal sexual behavior.

A previous study found that OT binding in estrogen primed females in the rostral region of the VMH was limited to neuronal cell bodies and was not affected by progesterone treatment (Schumacher et al., 1990). In contrast, binding in the caudal region of the $\mathrm{VMH}$ was evident in the ventrolateral region, and was mobilized to the surrounding region in the presence of progesterone. Anatomical studies of VMH projections have shown that the vIVMH is more closely related to other parts of the hypothalamus that also express gonadal steroid hormone receptors and where estrogen and progesterone binding tends to be concentrated (Canteras et al., 1994). In agreement with these previous OT binding studies, we detected OR mRNA in perikarya of the rostral VMH, and in the ventrolateral region of the caudal VMH on the afternoon of proestrus. This occurs at a time when estrogen and progesterone levels are nearly maximal.

The fact that the maximal changes in OR mRNA in the VMH occurred only when endogenous levels of estrogen were maximal and progesterone was also elevated is intriguing considering
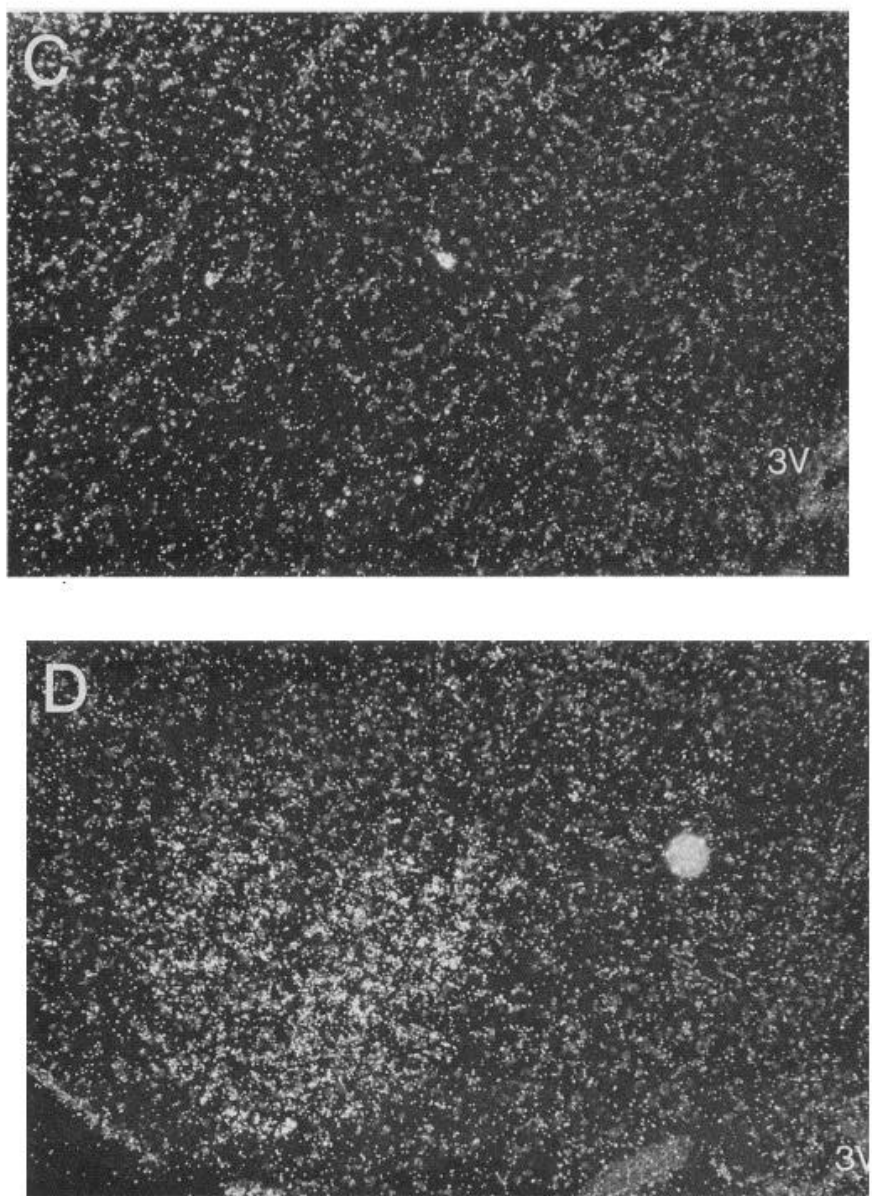

Figure 5. Photomicrographs of emulsion coated hybridized sections containing the rostral VMH. (A) vlVMH hybridization signal (dashed line) observed on 9:00 hr proestrus $(B)$ dmVMH hybridization signal (arrow) observed on 16:00 $\mathrm{hr}$ proestrus, compared to low signal observed in the vl region (dashed line). Photomicrographs of emulsion coated hybridized sections from the caudal VMH on (C) 9:00 hr proestrus showing little expression and $(D)$ at 16:00 $\mathrm{hr}$ proestrus showing prominent vlVMH signal for OR mRNA. 
that recent studies indicate that the ability of centrally administered OT to stimulate plasma LH is maximum only when physiologically high levels of estradiol are present along with elevated levels of progesterone (Gelineau-VanWaes and Johnston, 1994). What role the changes in ORs in the VMH play in the onset of the preovulatory increase in plasma $\mathrm{LH}$ remains to be determined in future studies, however, there are projections extending from the vIVMH to the medial preoptic area containing LHRH cell bodies (Canteras et al., 1994), thus providing a direct mechanism for $\mathrm{LH}$ regulation via ORs.

In summary, the present study suggests that induction of OR mRNA expression in the caudal regions of the vlVMH during the estrous cycle may be steroid hormone dependent, as it increased dramatically on the afternoon of proestrus at a time when estrogen and progesterone levels were both elevated. OR mRNA expression in the rostral regions of the VMH also appeared to be steroid hormone (most likely estrogen) dependent especially in its ventrolateral aspect. However, nonhormonal factors such as trans-synaptic inputs may also play a role in patterning of expression related to distribution in the ventrolateral versus dorsomedial aspects of the nucleus on the morning and the afternoon of proestrus.

\section{References}

Arletti R, Bertolini A (1985) Oxytocin stimulates lordosis behavior in female rats. Neuropeptides 6:247-253.

Bale TL, Dorsa DM (1995) Sex differences in and effects on oxytocin receptor messenger ribonucleic acid expression in the ventromedial hypothalamus. Endocrinology 136:27-32.

Bohus B, Kovacs GL, DeWied D (1978) Oxytocin, vasopressin, and memory: opposite effects on consolidation and retrieval processes. Brain Res 157:414-417.

Brinton RE, Wamsley JK, Gee KW, Wan YP, Yamamura HI (1984) ${ }^{3} \mathrm{H}$-Oxytocin binding sites in the rat brain demonstrated by quantitative light microscopic autoradiography. Eur J Pharmacol 102:365367.

Caldwell JD, Prange AF, Pedersen CA (1986) Oxytocin facilitates the sexual receptivity of estrogen-treated female rats. Neuropeptides 7:175-189.

Caldwell JD, Barakat AS, Smith DD, Hruby VJ, Pedersen CA (1990) A uterotonic antagonist blocks the oxytocin-induced facilitation of female sexual receptivity. Brain Res 512:291-296.

Canteras NS, Simerly RB, Swanson LW (1994) Organization of projections from the ventromedial nucleus of the hypothalamus: a Phaseolis vulgaris-leucoagglutinin study in the rat. J Comp Neurol 348:41-79.

Coirini H, Schumacher M, Flanagan LM, McEwen BS (1991) Transport of estrogen-induced oxytocin receptors in the ventromedial hypothalamus. J Neurosci 11:3317-3324.

Coirini H, Johnson AE, Schumacher M, McEwen BS (1992) Sex differences in the regulation of oxytocin receptors by ovarian steroids in the ventromedial hypothalamus of the rat. Neuroendocrinology 55:269-275.

DeKloet E, Rotteveel F, Voorhuis T, Terlou M (1985a) Topography of binding sites for neurohypophyseal hormones in rat brain. Eur $\mathbf{J}$ Pharmacol 110:113.

DeKloet ER, Voorhuis DAM, Elands J (1985b) Estradiol induces oxytocin binding sites in rat hypothalamic ventromedial nucleus. Eur J Pharmacol 118:185-186.

DeKloet ER, Voorhuis DAM, Boschma Y, Elands J (1986) Estradiol modulates density of putative 'oxytocin receptors' in discrete rat brain regions. Neuroendocrinology 44:415-421.

Fahrbach SE, Morrell JI, Pfaff DW (1985) Possible role of endogenous oxytocin in estrogen-facililated maternal behavior in rats. Neuroendocrinology 40:526-532.

Fehm-Wohlsdorf G, Born J, Voigt KH, Fehm HL (1984) Human memory and neurohypophyseal hormone: opposite effects of vasopressin and oxytocin. Psychoneuroendocrinology 9:285-292.

Ferrier BM, Kennet DJ, Devlin MC (1980) Influence of oxytocin on human memory processes. Life Sci 27:2311-2317.
Gelineau-VanWaes J, Johnston CA (1994) Role of gonadal steroids in the plasticity of CNS oxytocin neuronal interactions with LHRH. Proc West Pharmacol Soc 37:237 (abstract).

Gorzalka BB, Lester LLG (1987) Oxytocin-induced facilitation of lordosis behavior in rats is progesterone-dependent. Neuropeptides 10:55-65.

Johnson AE, Coirini H, Ball GF, McEwen BS (1989) Anatomical localization of the effects of $17 \mathrm{~B}$-estradiol on oxytocin receptor binding in the ventromedial nucleus. Endocrinology 124:207-211.

Johnson AE, Coirini H, Insel TR, McEwen BS (1991) The regulation of oxytocin receptor binding in the ventromedial hypothalamic nucleus by testosterone and its metabolites. Endocrinology 128:891896

Johnston CA, Gelineau-VanWaes J (1992) Physiological significance and interactions between oxytocin and central neuropeptide and monoamine neurotransmitters the regulation of the preovulatory secretion of luteinizing hormone. In: Annals of the New York Academy of Science, Oxytocin in maternal, sexual, and social behaviors (Pedersen CA, Caldwell JD, Jirikowski GF, Inscl TR, cds), pp 440442. New York: New York Academy of Sciences.

Johnston CA, Negro-Vilar A (1988) Role of oxytocin on prolactin secretion during proestrous and in different physiological or pharmacological paradigms. Endocrinology 122:341-350.

Johnston CA, Lopez F, Samson WK, Negro-Vilar A (1990) Physiologically important role for central oxytocin in the preovulatory release of luteinizing hormone. Neurosci Lett 120:256-258.

Mani SK, Blaustein JD, Allen JMC, Law SW, O'Malley BW, Clark JH (1994) Inhibition of rat sexual behavior by antisense oligonucleotides to the progesterone receptor. Endocrinology 135:14091414.

McCarthy MM, Kleopoulos SP, Mobbs CV, Pfaff DW (1994) Infusion of antisense oligodeoxynucleotides to the oxytocin receptor in the ventromedial hypothalamus reluces estrogen-induced sexual receptivity and oxytocin receptor binding in the female rat. Neuroendocrinology 59:432-440.

Ogawa S, Olazabal UE, Parhar IS, Pfaff DW (1994) Effects of intrahypothalamic administration of antisense DNA for progesterone receptor mRNA on reproductive behavior and progesterone receptor immunoreactivity in female rat. J Neuroscience 14:1766-1774.

Pedersen CA, Prange AJ Jr (1979) Induction of maternal behavior after intracerebroventricular administration of oxytocin. Proc Natl Acad Sci USA 76:6661-6665.

Pollio G, Xue P, Zanisi M, Nicolin A, Maggi A (1993) Antisense oligonucleotide blocks progesterone-induced lordosis behavior in ovariectomized rats. Mol Brain Res 19:135-139.

Raggenbaus M, Tribollet E, Dubois-Dauphin M, Dreifuss JJ (1989) Correlation between oxytocin neuronal sensitivity and oxytocin receptor binding: an electrophysiological and autoradiographical study comparing rat and guinea pig hippocampus. Proc Natl Acad Sci USA 86:750-754.

Schumacher M, Coirini H, Frankfurt M, McEwen BS (1989) Localized actions of progesterone in hypothalamus involve oxytocin. Proc Natl Acad Sci USA 86:6798-6801.

Schumacher M, Coirini H, Pfaff DW, McEwen BS (1990) Behavioral effects of progesterone associated with rapid modulation of oxytocin receptors. Science 250:691-694.

Schumacher M, Coirini H, Johnson AE, Flanagan LM, Frankfurt M, Pfaff DW, McEwen BS (1993) The oxytocin receptor: a target for steroid hormones. Regul Peptides 45:115-119.

Smith MS (1989) Lactation. In: Textbook of physiology, Vol 2 (Patton HD, Fuchs AF, Hille B, Scher AM, Steiner RS, eds), pp 1408 1421. Philadelphia: Saunders.

Tribollet E, Barberis C, Jard S, Dubois-Dauphin M, Dreifuss JJ (1988) Localization and pharmacological characterization of high affinity binding sites for vasopressin and oxytocin in the rat brain by light microscopic autoradiography. Brain Res 442:105-108.

Tribollet E, Audigier S, Dubois-Dauphin M, Dreifuss JJ (1990) Gonadal steroids regulate oxytocin receptors but not vasopressin receptors in the brain of male and female rats. An autoradiographical study. Brain Res 511:129-140

Van Leengoed E, Kerker E, Swanson HH (1987) Inhibition of postpartum maternal behavior in the rat by injecting an oxytocin antagonist into cerebral ventricles. J Endocrinology 112:275-282.

Van Leeuwen FW, Van Heerikhuize JJ, VanDerMeulen G, Wolters P (1985) Light microscopic autoradiographic localization of ${ }^{3} \mathrm{H}-0 x y-$ 
tocin binding sites in the rat brain, pituitary, and mammary gland. Brain Res 359:320-325.

Walter R, Hoffman PL, Flexner JB, Flexner LB (1975) Neurohypophyseal hormones, analogs, and fragments: their effect on puromycin-induced amnesia. Proc Natl Acad Sci USA 72:4180-4184.
Witt DM, Insel TR (1991) A selective oxytocin antagonist attenuates progesterone facilitation of female sexual behavior. Endocrinology $128: 3269-3276$ 